\title{
PERENCANAAN STRATEGIS SISTEM INFORMASI MENGGUNAKAN METODE WARD AND PEPPARD PADA PT. SERASI AUTORAYA
}

\author{
Amsal lah $^{1)}$,Yani Rahardja ${ }^{2)}$, dan Melkior Nikolar Ngalumsine Sitokdana ${ }^{3)}$ \\ ${ }^{1,2,3}$ Program Studi Sistem Informasi, Fakultas Teknologi Informasi, Universitas Kristen Satya Wacana \\ 1,2,3 Jl. Blotongan, Sidorejo Lor, Sidorejo, Kota Salatiga, Jawa Tengah 50714 \\ E-mail: 682015053@student.uksw.edu ${ }^{1)}$,yani.rahardja@uksw.edu ${ }^{2)}$, melkior.sitokdana@uksw.edu ${ }^{3)}$
}

\begin{abstract}
ABSTRAK
PT.Serasi Autoraya (trac) merupakan perusahaan yang bergerak di bidang layanan transportasi yang menawarkan jasa dalam penyewaan unit kendaraan baik kepada perusahaan, individu, maupun layanan pengemudi yang profesional. PT.Serasi Autoraya (trac) masih mempuyai kendala dalam Infrastruktur dan aplikasi SI belum mampu mendukung proses bisnis dan kurangnya implementasi SI membuat kinerja menjadi tidak effisien. Salah satu penyebabnya adalah belum cukup memiliki sumber daya manusia yang memiliki kecakapan dalam melakukan pengelolaan sistem informasi dan teknologi informasi secara baik. Dalam penyusunan kerangka kerja perencanaan strategis sistem informasi menggunakan pendekatan Ward and Peppard. Analisis lingkungan internal dan eksternal bisnis menggunakan Value Chain analysis dan SWOT analysis. Sedangkan pemetaan portofolio aplikasi menggunakan McFarlan Strategic Grid. Pada akhirnya penelitian ini menghasilkan sebuah rekomendasi untuk dikembangkan diantarnya Pengembangan Website Trac, Pengembangan aplikasi SAP, Pengembangan Aplikasi sistem infromasi layanan pelanggan, Aplikasi sistem infromasi aset dan Pengembangan Sistem Informasi Eksekutif. Dengan harapan untuk memberikan kejelasan arah dan mendorong perusahaan untuk terus berkembang baik dari aspek SDM SI dan pengembangan aplikasi portofolio yang akan mendukung kelangsungan proses bisnis di PT.Serasi Autoraya (Trac).
\end{abstract}

Kata Kunci: Perencanaan Strategis, Sistem Informasi, Aplikasi SAP, Ward and Peppard

\section{PENDAHULUAN}

Dalam pembangunan sebuah sistem informasi dibutuhkan perencanaan yang baik agar sistem informasi yang dikembangkan dapat berjalan sesuai dengan kebutuhan bisnis. Sehingga data dan informasi yang di hasilkan dapat berkulitas, konsisten dan tidak terpisahpisah. Begitu juga didalam dunia bisnis. Persaingan bisnis yang semakin tinggi membuat setiap organisasi mau tidak mau harus meng-update atau mengembangkan sistem informasi. Terbukti bahwa saat ini hampir semua organisasi membutuhkan SI yang semakin berkembang dari tahun ke tahun membuat komponen-komponen penunjangnya pun semakin berkembang. Namun tidak terpungkiri bahwa organisasi memiliki keterbatasan sumber daya, maka dibutuhkan perencanaan strategis sistem informasi dalam organisasi agar sumber daya dapat direncanakan dan diimplementasikan dengan baik. Perusahaan di PT. Serasi Autoraya (trac) Semarang perusahaan yang bergerak di bidang Layanan transportasi yang menawarkan jasa dalam penyewaan unit kendaraan baik kepada perusahaan (jangka panjang), individual (jangka pendek), layanan bus, penyewaan motor, maupun layanan pengemudi yang profesional. Namun, kurangnya pemanfaatan SI/TI belum dapat membantu menyelesaikan masalah yang ada di PT. Serasi Autoraya (trac). Infrastruktur dan aplikasi SI/TI belum mampu mendukung proses bisnis dan memberikan keunggulan kompetitif. Salah satu penyebabnya adalah belum cukup memiliki sumber daya manusia yang memiliki kecakapan dalam melakukan pengelolaan sistem informasi dan teknologi informasi secara baik. Selain, pengembangan teknologi informasi dilakukan tanpa perencanaan yang baik sehingga mengakibatkan tidak maksimalnya investasi dalam SI/TI. Berdasarkan permasalahan yang ditemukan pada PT. Serasi Autoraya (Trac) perencanaan strategis bermaksud memberikan kejelasan arah dan mendorong perusahaan untuk terus berkembang baik dari aspek sumber daya Sistem Informasi dan Teknologi Informasi.

Dalam penelitian ini dilakukan perancangan rencana strategis Sistem Informasi dan Teknologi Informasi menggunakan metode Ward and Peppard. Pada metode ini akan dilakukan beberapa tahap, dan masing-masing akan menggunakan beberapa metode, antara lain; Analisis lingkungan internal dan eksternal bisnis menggunakan metode SWOT sedangkan analisis lingkungan internal dan eksternal SI/TI menggunakan SWOT dan Value Chain. Kemudian pemetaan portofolio aplikasi menggunakan metode Mcfarland Strategic Grid.

Penelitian tentang perencaan strategis sistem informasi bukanlah merupakan hal baru, maka beberapa penelitian yang relevan dijadikan sebagai acuan dalam penelitian ini, adalah sebagai berikut:

Penelitian tentang Perencanaan Strategis Sistem Informasi Untuk Meningkatkan Pelayanan Menggunakan Metode Ward And Peppard Studi Kasus PT Pos 
Indonesia Cilegon-Banten. Pada penelitian tersebut mengatakan Perencanaan Strategik Sistem Informasi dapat digunakan untuk menyelaraskan antara kebutuhan strategi bisnis, dan strategi SI/TI untuk mendapatkan nilai tambah organisasi dari segi keunggulan kompetitif. Oleh karena itu, penelitian tersebut merekomendasikan pengembangan Sistem Informasi layanan Coorporate, Sistem Informasi Pelanggan, Sistem Informasi Pembelian dan SMS Gateway, Aplikasi Informasi produk pos dan Aplikasi Keluhan pelanggan (Anharudin, 2015).

Penelitian tentang Perencanaan Strategis Sistem Informasi Dan Teknologi Informasi SI/TI Pendidik Dan Tenaga Kependidikan (Studi Kasus: Pada Disdikbudpora Metro). Dalam penelitian tersebut mengatakan penyusunan perencanaan strategis SI/TI sesuai portofolio SI/TI yang dihasilkan dapat digunakan dalam perencanaan strategis periode mendatang sehingga dapat memberikan prioritas pada aktivitas yang dibutuhkan untuk memperoleh hasil yang optimal dan berdasarkan kontribusinya pada tujuan yang akan dicapai. Oleh karena itu, penelitian tersebut menghasilkan blue print perencanaan strategis yang mengacu pada rencana bisnis organisasi berdasarkan data yang diperoleh melalui metode analisis yang digunakan (Arifani dan Darmawan, 2016).

Penelitian tentang Perencanaan Strategi Sistem Informasi/Teknologi Informasi Universitas Lancang Kuning Menggunakan Metode Ward and Peppard. Dalam penelitian tersebut mengatakan untuk menjawab tantangan menjadi organisasi yang unggul, maka dibutuhkan penyelarasan proses dan sistem teknologi informasi dan proses bisnis organisasi. Oleh karena itu, beberapa hal yang direkomendasikan dalam penelitian tersebut, yaitu: Roadmap pengembangan TI/SI yang lebih difokuskan pada SI Akademik, Restrukturisasi jaringan internet, e-learning dan SI Penjaminan Mutu. Hal tersebut bermanfaat dalam mencapai tujuan Universitas Lancang Kuning unggul 2030 (Syafitri, 2015).

Penelitian tentang Perencanaan Strategis Sistem Informasi PT.FM Guna Meningkatkan Daya Saing Menggunakan Metode Ward \& Peppard. Pada penelitian tersebut mengatakan Strategi SI/TI diperlukan untuk menyelaraskan SI/TI dengan strategi bisnis perusahaan. Dengan demikian TI akan mendukung bisnis, bahkan menciptakan peluang baru untuk meningkatkan daya saing bisnis. Oleh karena itu, penelitian tersebut mengusulkan pengembangan beberapa sistem informasi, yaitu: penambahan modul SCM, CRM, KM, peningkatan modul JIT, ERP, homepage disertai perbaikan infrastruktur jaringan (Setiawan, 2016).

Beberapa peneltiian terdahulu yang diuraikan di atas dapat dijadikan sebagai acuan dalam penelitian ini. Bebererapa metode yang digunakan hampir sama dengan penelitian terdahulu, seperti SWOT, Value Chain dan Mc Farlan Strategic Grid, tetapi lokus penelitiannya berbeda dan hanya menyusun rencana strategis sistem informasinya, tidak termasuk hardware, brainware, jaringan, database dan prosedur. Dengan demikian, harapannya penelitian ini dapat memberikan rekomendasi portfolio aplikasi yang akan dikembangkan dimasa mendatang.

\section{RUANG LINGKUP}

Ruang lingkup penelitian ini adalah sebagai berikut:

1. Cakupan permasalahan dalam penelitian ini adalah: Penerapan Sistem Informasi/Teknologi Informasi di PT.Serasi Autoraya (trac) selama ini dilakukan tanpa perencanaan yang baik sehingga mengakibatkan tidak maksimalnya investasi TI. Oleh karena itu, dibutuhkan perencanaan strategis SI agar memberikan kejelasan arah dan mendorong perusahaan untuk terus berkembang baik dan memiliki keunggulan kompetitif

2. Batasan penelitian ini adalah hanya fokus pada rencana strategis Sistem Informasi (aplikasi SI), tidak membahas rencana pengembangan hardware, Jaringan, Database, Sumber Daya Manusia dan prosedur.

3. Rencana hasil yang didapatkan dari penelitian ini adalah merekomendasikan portfolio aplikasi Sistem Informasi untuk dikembangkan dalam jangka waktu 5 (lima) tahun

\section{BAHAN DAN METODE}

Berikut disajikan bahan kajian, metode dan tahapan penelitian yang dilakukan

\subsection{Perencaaan Strategis Sistem Informasi}

Perencanaan strategis adalah suatu rencana jangka panjang yang bersifat menyeluruh, memberikan rumusan terhadap suatu perusahaan/organisasi mengenai arahan dan bagaimana sumber daya dialokasikan untuk mencapai tujuan selama jangka waktu tertentu dalam berbagai kemungkinan keadaan lingkungan (Septiana, 2017).

Pengertian sistem informasi menurut Alter (1992), sistem informasi adalah kombinasi prosedur kerja, orang, dan teknologi infromasi yang diorganisasikan untuk mencapai tujuan dalam sebuah organiasai. Sedangkan pengertian sistem informasi menurut Bodnar dan Hopwood (1993), sistem informasi adalah kumpulan perangkat lunak yang dirancang untuk mentransformasikan data ke dalam bentuk infomasi yang berguna(Kadir, 2014).

Definisi Perencanaan Strategis SI/TI menurut Ward and Peppard (2002) adalah suatu proses identifikasi portofolio aplikasi SI berbasis komputer yang akan mendukung organisasi dalam pelaksanaan rencana bisnis dan merealisasikan tujuan bisnisnya. Perencanaan strategis SI/TI mempelajari pengaruh SI/TI terhadap kinerja bisnis dan kontribusi bagi organisasi dalam memilih langkah-langkah strategis. Selain itu, perencanaan strategis SI/TI juga menjelaskan berbagai tools, teknik, dan kerangka kerja bagi manajemen untuk menyelaraskan strategi SI/TI dengan strategi bisnis, 
bahkan mencari kesempatan baru melalui penerapan teknologi yang inovatif (Wibowo dan Wijaya, 2018). Pengertian lainnya, strategi Sistem Informasi sebagai suatu penggunaan teknologi informasi untuk mendukung atau menerapkan strategi kompetisi dari perusahaan dan pemanfaatannya dapat meningkatkan daya saing (Kurniadi dan Mulyani, 2016).

Menurut Pant dan Hsu (1995) beberapa karakteristik dari perencanaan strategis SI/TI antara lain adalah adanya misi utama; keunggulan strategis atau kompetitif dan kaitannya dengan strategi bisnis; adanya arahan dari eksekutif atau manajemen senior dan pengguna; serta pendekatan utama berupa inovasi pengguna dan kombinasi pengembangan bottom up dan analisis top down(Santoso, Rasidi dan Arif, 2018).

\subsection{Metodologi Ward and Pepard}

Penelitian ini menggunakan metodologi Ward and Peppard. Metodologi tersebut dapat digambarkan sebagai berikut:

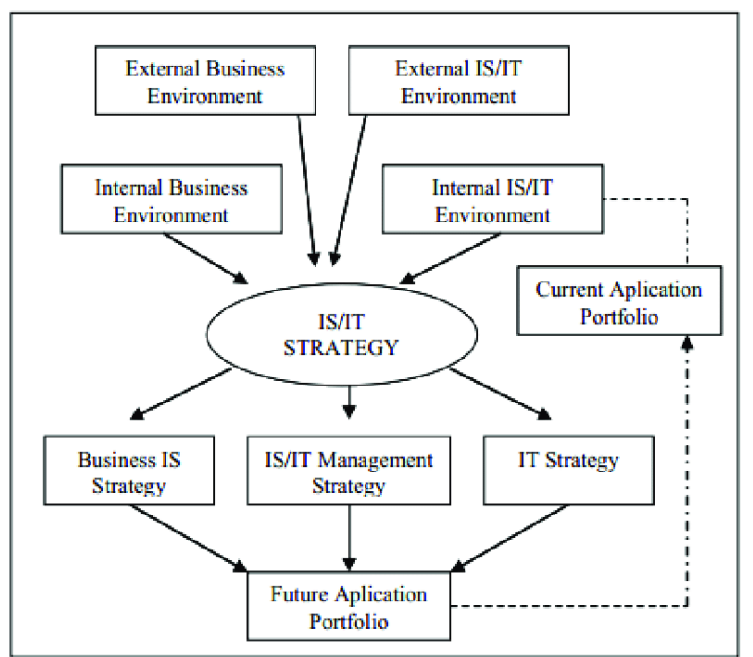

\section{Gambar 1. Model Strategis Sistem Informasi (Ward dan Peppard, 2002)}

Tahapan metodologi Ward and Pepapard pada Gambar 1. dapat dijelaskan sebagai berikut (Septiana, 2017) :

Tahapan Masukan:

1. Analisis Lingkungan bisnis internal: Strategi Bisnis sekarang, tujuan (objektif), sumber daya, proses, dan kebudayaan serta nilai dari suatu bisnis.

2. Analisis Lingkungan bisnis eksternal: ekonomi, lingkungan industri, iklim persaingan dimana organisasi beroperasi.

3. Analisis Lingkungan SI/TI internal: perspektif SI/TI sekarang di bisnis, kematangannya, ruang lingkup dan kontribusi bisnis, skill, sumber daya dan infrastruktur teknologi. Portofolio aplikasi dari sistem yang ada sekarang dan sistem yang sedang dikembangkan, atau sudah dianggarkan tetapi belum selesai juga merupakan bagian dari lingkungan SI/TI internal.
4. Analisis Lingkungan SI/TI eksternal: tren teknologi dan kesempatan serta kegunaan yang dihasilkan oleh SI/TI pihak lain, terutama customer, pesaing dan supplier.

Tahapan keluaran yaitu:

1. Strategi Bisnis SI: bagaimana setiap unit atau fungsi akan mengembangkan SI/TI dalam mencapai tujuan (objektif) bisnisnya.

2. Strategi manajemen SI/TI: elemen-elemen yang lazim dari strategi yang diterapkan organisasi secara keseluruhan, menjamin kebijakan konsisten yang dibutuhkan.

3. Strategi SI/TI: kebijakan dan strategi untuk menajemen teknologi dan ahli sumber daya.

\subsection{Tahapan penelitian}

Penelitian ini dilakukan dengan beberapa tahap, yaitu:

1. Identifikasi masalah

Identifikasi masalah merupakan salah satu proses dimana peneliti mendapatkan suatu gambaran tentang permasalahan yang ada untuk memberikan solusi dengan melakukan pengamatan lapangan (observasi).

2. Studi pustaka

Langkah awal yang harus dilakukan oleh peneliti adalah melakukan studi pustaka untuk mendukung proses penulisan. Dengan melakukan studi kasus dapat memperkuat dan dapat mengembangkan topik yang akan dibahas oleh peneliti pada penelitian ini. Sehingga dengan melakukan studi pustaka, penulis mendapatkan gambaran tentang perencanaan strategis sistem informasi serupa yang sudah dilakukan oleh peneliti lain.

3. Pengumpulan Data

Penelitian ini bertujuan untuk mengamati lingkungan sekitar untuk mendapatkan data-data yang dibutuhkan yang berhubungan dengan proses penyusunan perencanaan strategi sistem infromasi dan mengamati proses bisnis serta penggunaan SI/TI sehingga peneliti mendapatkan ide untuk membuat PSSI menggunakan metode ward and peppard dan melakukan tahapan analisa. Dalam pengumpulan data ini dilakukan dengan teknik yaitu:

1) Melakukan Wawancara :

Wawancara di lakukan pada Manager/Kepala PT. Serasi Autoraya (trac) Kota Semarang dan beberapa karyawan, pada tanggal 15 November 2018.

2) Melakukan Observasi :

Observasi dilakukan pada tanggal 03 September 2018 - 30 November 2018 di PT. Serasi Autoraya (trac) Kota Semarang.

3) Melakukan Dokumentasi :

Melakukan analisis mengenai dokumen-dokumen meliputi visi misi, struktur organisasi, infrastruktur SI/TI. Data tersebut nantinya dijadikan sebagai acuan untuk melakukan perancangan strategis di PT. Serasi Autoraya (trac) Kota Semarang. 
4. Analisis Perencanaan Strategis Sistem infromasi menggunakan metode Ward And Peppard. Tahapannya adalah sebagai berikut:

1) Analisis Lingkungan Bisnis Internal pada tahap ini, yang harus dipahami adalah segala sesuatu yang berhubungan dengan kegiatan bisnis internal PT. Serasi Autoraya (trac) sedangkan Analisis Lingkungan Eksternal Bisnis pada tahap ini, yang harus dipahami adalah faktor eksternal yang mempengaruhi proses bisnis PT. Serasi Autoraya (trac) metode yang digunakan ialah SWOT.

2) Analisis Lingkungan Internal SI Organisasi pada tahap ini, yang harus dipahami adalah apa saja SI yang sudah di implementasi pada PT. Serasi Autoraya (trac) sedangkan Analisis Lingkungan Eksternal SI organisasi pada tahap ini, yang harus di pahami adalah trend apa saja pada SI yang sedang berkembang diluar dan seberapa cocok untuk diimplementasikan di PT. Serasi Autoraya (trac). Analisis berguna untuk mengetahui perkembangan teknologi diluar dan menelaah teknologi tersebut guna dimanfaatkan dalam mendukung perencanaan strategis bisnis PT. Serasi Autoraya (trac) disaat yang akan datang. Metode yang digunakan adalah Value Chain.

3) Portofolio Aplikasi

4) Konsep portofolio aplikasi bertujuan untuk menemukan sistem informasi yang digunakan dalam penyusunan usulan pengembangan aplikasi yang disesuaikan dengan portofolio aplikasi Mc Farlan Strategic Grid, berdasarkan hasil analisis maka penyusunan strategi dibuat dan disesuaikan dengan kebutuhan SI/TI hingga menghasilkan Rancangan Strategi SI/TI untuk kedepannya di PT. Serasi Autoraya (trac).

5. Rencana Implementasi

Rencana Implementasi Perencanaan strategis ini diusulkan untuk diimplementasikan dalam jangka waktu 5 tahun.

\section{PEMBAHASAN}

PT.Serasi Autoraya (Trac) adalah sebuah perusahaan yang berdiri sejak tahun 1986, dimana perusahaan merupakan perusahaan penyedia jasa solusi transportasi terdepan di indonesia bermula dengan hanya 5 unit kendaraan, kini perusahaan sudah memiliki lebih dari 30.000 kendaraan yang beroperasi dilebih dari 3.900 pelanggan segmen korporat. Lebih dari 25 tahun pengalaman di bisnis jasa transportasi, membuat perusahaan ini matang dan menguasai seluk beluknya. Publik mempercayai layanan ini dengan memberi penghargaan indonesia Service Quality Award 2011, The Most Recommended Brand 2011, The Indonesia Best Brand Award In Car Rental Business 2011, Indonesia Superbrands 2012, and Top Brand Ward 2012.

\subsection{Analisis Lingkungan Internal/Eksternal Bisnis}

$$
\text { Analisis SWOT (Strengths, Weaknesses, }
$$$$
\text { Opportunities, Threats) digunakan untuk menilai }
$$

kekuatan - kekuatan dan kelemahan - kelemahan dari sumber daya yang dimiliki oleh perusahaan PT.Serasi Autoraya (Trac) dan kesempatan - kesempatan eksternal dan tantangan - tantangan yang dihadapi. Analisis internal mengunakan metode SWOT yaitu dengan melihat kekuatan dan kelemahan yang ada didalam perusahaan. Sedangkan peluang dan ancaman adalah faktor yang berasal dari luar perusahaan. Berikut adalah tabel Analisis SWOT untuk memetahkan Lingkungan Internal/Eksternal Bisnis.

Tabel 1. Analisis SWOT

\begin{tabular}{|c|c|c|}
\hline & Kekuatan (S) & Kelemahan (W) \\
\hline Eksternal & $\begin{array}{ll}\text { 1. } & \text { Tersedia } \\
\text { produk-produk } \\
\text { kendaraan } \\
\text { yang } \\
\text { berkualitas } \\
\text { 2. } \\
\begin{array}{l}\text { Driver yang } \\
\text { berkualitas dan } \\
\text { berpengalaman } \\
\text { 3emiliki } \\
\text { service quality } \\
\text { yang baik }\end{array}\end{array}$ & $\begin{array}{l}\text { 1. SDM dalam } \\
\text { bidang IT } \\
\text { terbatas } \\
\text { 2. Infrastruktur } \\
\text { yang ada kurang } \\
\text { memadai } \\
\text { 3. Kurangnya } \\
\text { Jumlah karyawan }\end{array}$ \\
\hline Peluang (O) & Strategis S-O & Strategis $\mathrm{W}-\mathrm{O}$ \\
\hline 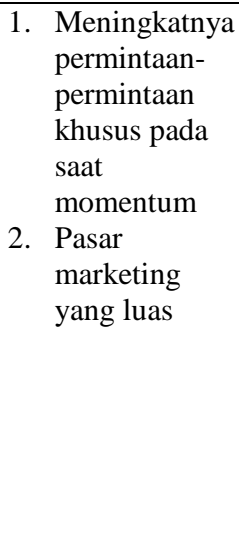 & 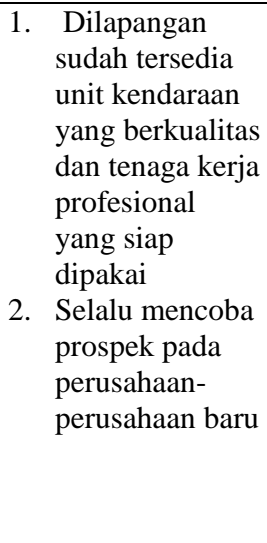 & $\begin{array}{l}\text { 1. Membangun } \\
\text { Sistem Informasi } \\
\text { yang baru sesuai } \\
\text { kebutuhan } \\
\text { organisasi . } \\
\text { 2. Menginvestasi } \\
\text { kekurangan } \\
\text { infrastruktur yang } \\
\text { ada } \\
\text { 3. Melakukan } \\
\text { perekrutan } \\
\text { pegawai baru } \\
\text { untuk mengisi } \\
\text { posisi yang masih } \\
\text { kosong }\end{array}$ \\
\hline Ancaman (T) & Strategis S-T & Strategis W-T \\
\hline 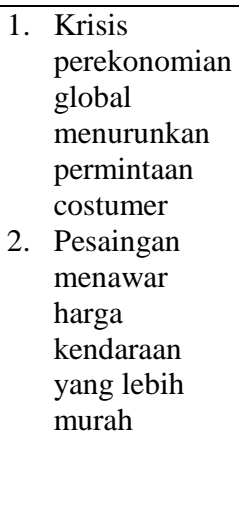 & $\begin{array}{ll}\text { 1. } & \text { Meningkatkan } \\
\text { kualitas } \\
\text { kendaraan dan } \\
\text { melakukan } \\
\text { promosi } \\
\text { 2. Memiliki } \\
\text { kendaraan } \\
\text { yang } \\
\text { berkualitas dan } \\
\text { adanya } \\
\text { asuransi dari } \\
\text { perusahaan } \\
\text { untuk } \\
\text { costumer }\end{array}$ & $\begin{array}{ll}\text { 1. } & \text { Meningkatkan } \\
\text { kompetensi } \\
\text { SDM SI } \\
\text { 2. Memiliki driver } \\
\text { yang lulus } \\
\text { sertifikasi (Trac) }\end{array}$ \\
\hline
\end{tabular}

Analisis Value Chain adalah analisis yang dilakukan untuk memetakan seluruh proses bisnis yang ada PT. Serasi Autoraya (Trac) yang digolongkan menjadi 
aktivitas utama dan aktivitas pendukung. Berikut ini adala gambar dari analisis Value chain.

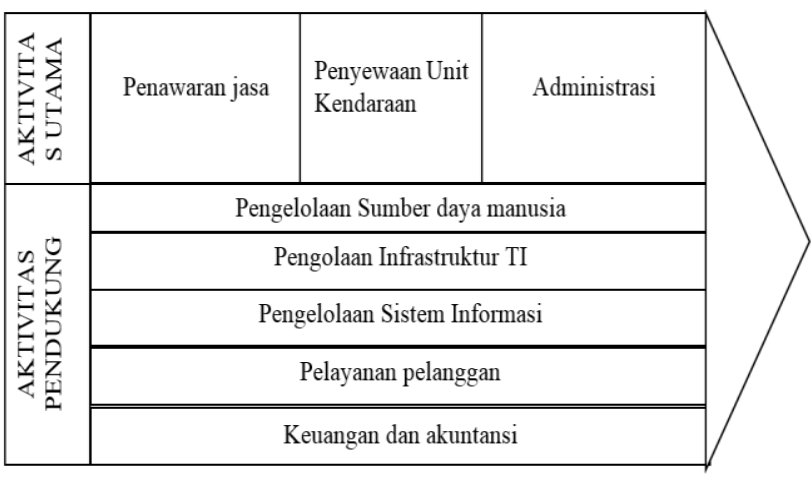

Gambar 1. Hasil Analisis Value Chain

Berdasarkan gambar 2, dijadikan sebagai berikut

1. Aktivitas Utama (Main Activity) terdiri dari :

1) Penawaran jasa

2) Penyewaan unit kendaraan

3) Administrasi

2. Aktivitas Pendukung (Support Activity) terdiri dari :

4) Pengelolaan sumber daya manusia

5) Pengelolaan infrastruktur TI

6) Pengelolaan sistem informasi

7) Pelayanan pelanggan

8) Keuangan dan akuntansi

Setelah mengetahui aktivitas utama dan pendukung yang berada di PT. Serasi Autoraya (Trac) maka akan dilanjutkan dengan menganalisa hubungan antara stakeholder dengan aktivitas utama dan pendukung sehingga dapat mengetahui mengenai aktivitas stakeholder tersebut. Berikut Tabel hubungan antara stakeholder dengan aktivitas yang berada di PT. Serasi Autoraya (Trac) .

Tabel 2. Hubungan Stakeholder dengan Aktivitas Organisasi

\begin{tabular}{|c|c|c|}
\hline Stakeholder & $\begin{array}{c}\text { PT. Serasi } \\
\text { Autoraya (Trac) }\end{array}$ & Pelanggan \\
\hline $\begin{array}{ll}\text { 1) } & \text { Aktivitas Utama } \\
\text { 2) } & \text { Penawaran jasa } \\
& \text { kendaraan unit } \\
\text { 3) } & \text { Administrasi }\end{array}$ & $\begin{array}{l}\text { Direktur, } \\
\text { Manager, sales } \\
\text { manager, } \\
\text { administrasi }\end{array}$ & $\begin{array}{c}\text { Costumer / } \\
\text { Nasabah }\end{array}$ \\
\hline
\end{tabular}

\begin{tabular}{|c|c|c|c|}
\hline \multicolumn{2}{|c|}{ Aktivitas Pendukung } & \multirow{6}{*}{$\begin{array}{l}\text { Direktur, } \\
\text { Manager, sales } \\
\text { manager, Staff, } \\
\text { seluruh } \\
\text { karyawan, } \\
\text { administrasi }\end{array}$} & \multirow{6}{*}{$\begin{array}{l}\text { Costumer / } \\
\text { Nasabah }\end{array}$} \\
\hline 1) & $\begin{array}{l}\text { Pengelolaan } \\
\text { sumber daya } \\
\text { manusia }\end{array}$ & & \\
\hline 2) & $\begin{array}{l}\text { Pengelolaan } \\
\text { infrastruktur TI }\end{array}$ & & \\
\hline 3) & $\begin{array}{l}\text { Pengelolaan } \\
\text { sistem informasi }\end{array}$ & & \\
\hline 4) & $\begin{array}{l}\text { Pelayanan } \\
\text { pelanggan }\end{array}$ & & \\
\hline 5) & $\begin{array}{l}\text { Keuangan } \\
\text { akuntansi }\end{array}$ & & \\
\hline
\end{tabular}

\subsection{Analisis Lingkungan Internal SI/TI dan} Eksternal SI/TI

Saat ini aplikasi yang digunakan perusahaan PT.Serasi Autoraya (Trac) hanya berbasis aplikasi System Application and Product. Oleh karena itu kebutuhan bisnis dan layanan terhadap pelanggan yang bersifat spesifik belum terakomodasi dengan baik, sehingga masih dibutuhkan berbagai aplikasi. Sementara dari aspek hardware sudah tersedia dan memenuhi standar operasional perusahaan, seperti komputer ratarata menggunakan Corei3, RAM 2 GB dan Harddisk 500. Dari aspek jaringan cukup memadai, yaitu semua unit organisasi terhubung jaringan lokal dan internet. Namun yang menjadi kendala selama ini adalah kapasitas SDM dalam bidang IT kurang, terutama teknisi. Hal tersebut sering mempengaruhi kinerja organisasi apabila terjadi gangguan pada perangkat hardware. Oleh karena itu, dibutuhkan pelatihan peningkatan kapasitas SDM.

\subsection{Portofolio Aplikasi}

Berdasarkan hasil penjabaran strategi SI/TI dan strategi bisnis, maka terbentuklah aplikasi portofolio dengan prioritas dan blueprint strategis SI/TI yang berpedoman pada Mc Farlan Strategic Grid. Metode tersebut digunakan untuk memetakan aplikasi SI berdasarkan konstribusinya terhadap organisasi. Pemetaan dilakukan pada empat kuadran (strategic, high potential, key operation, and support). Dari hasil pemetaan tersebut didapat gambaran konstribusi sebuah aplikasi SI terhadap organisasi dan pengembangan dimasa mendatang. Berikut adalah Tabel portofolio aplikasi masa mendatang.

Tabel 3. Portofolio Aplikasi

\begin{tabular}{|ll|ll|}
\hline \multicolumn{2}{|c|}{ Strategic } & & High Potential \\
\hline 1) & $\begin{array}{l}\text { Aplikasi sistem } \\
\text { informasi } \\
\text { Eksekutif }\end{array}$ & 1) & Aplikasi Website Trac \\
\hline 2) & Aplikasi SAP & 1) & $\begin{array}{l}\text { Aplikasi sistem } \\
\text { informasi layanan } \\
\text { pelanggan } \\
\end{array}$ \\
& 2) \\
& & $\begin{array}{l}\text { Aplikasi sistem } \\
\text { infromasi aset }\end{array}$ \\
\hline Key Operational & & Support \\
\hline
\end{tabular}


Keterangan Tabel 3 :

1. Strategic merupakan aplikasi-aplikasi yang sangat rentang terhadap proses bisnis yang berada di PT.Serasi Autoraya (Trac)

2. Key Operational merupakan aplikasi-aplikasi yang saat ini menjadi keberhasilan PT.Serasi Autoraya (Trac)

3. High Potential merupakan aplikasi-aplikasi yang menjadi potensial dalam meningkatkan PT.Serasi Autoraya (Trac) yang akan datang.

4. Support merupakan aplikasi-aplikasi yang sangat berharga namun tidak menjadikan bergantungnya kesuksesan PT.Serasi Autoraya (Trac).

PT.Serasi Autoraya (Trac) telah tersedia beberapa aplikasi yang dapat mempermudah proses binsisnya adalah aplikasi Pengolahan Data. Berdasarkan wawancara dan observasi ditemukan berbagai persoalan yang mengakibatkan tidak berkembangnya PT.Serasi Autoraya (Trac). Oleh karena itu diusulkan beberapa aplikasi yang dapat di terapakan untuk mendukung proses bisnisnya. Usulan aplikasi dan prioritas pengembangan di petakan menggunakan Mc Farlan Strategic Grid yang terdiri dari 4 kategori. Berdasarkan pemetaan maka direkomendasikan prioritas pengembangan aplikasi. sebagai berikut:

1. Tahap pertama adalah pengembangan key oprational karena aplikasi ini menjadi kunci keberhasilan PT.Serasi Autoraya (Trac).

2. Tahap kedua adalah pengembangan Strategic karena aplikasi-aplikasi ini sangat berpengaruh terhadap berlangsungnya proses bisnis yang ada di PT.Serasi Autoraya (Trac).

3. Tahap ketiga adalah pengembangan Support, karena dengan adanya support aplikasi dapat membantu setiap proses binsnis di PT.Serasi Autoraya (Trac).

4. Tahap Keempat High Potential karena aplikasiaplikasi ini menajdi penentu perkembangan PT. Serasi Autoraya (Trac) yang akan datang.

\subsection{Rencana Implementasi}

Rencana implementasi terdiri dari perencanaan jangka pendek meliputi periode 1 sampai 2 tahun, sedangkan pencanaan jangka panjang meliputi periode sampai dengan 5 tahun. Dalam penelitian ini direkomendasikan untuk implementasikan dalam jangka waktu 5 (lima) tahun. Berikut adalah tabel rencana implementasinya.
Tabel 4. Rencana Implementasi SI di PT.Serasi Autoraya (Trac)

\begin{tabular}{|l|c|c|c|c|c|}
\hline \multirow{2}{*}{ Rekomendasi } & \multicolumn{5}{|c|}{ Tahun } \\
\cline { 2 - 6 } & 2019 & 2020 & 2021 & 2022 & 2023 \\
\hline $\begin{array}{l}\text { Aplikasi } \\
\text { SAP }\end{array}$ & & $\mathrm{v}$ & & & \\
\hline $\begin{array}{l}\text { Aplikasi } \\
\text { Website Trac }\end{array}$ & & & $\mathrm{v}$ & & \\
\hline $\begin{array}{l}\text { Aplikasi } \\
\text { sistem } \\
\text { informasi } \\
\text { Eksekutif }\end{array}$ & & & & $\mathrm{v}$ & \\
\hline $\begin{array}{l}\text { Aplikasi } \\
\text { sistem } \\
\text { informasi } \\
\text { layanan } \\
\text { pelanggan }\end{array}$ & & & & & \\
\hline $\begin{array}{l}\text { Aplikasi } \\
\text { sistem } \\
\text { infromasi } \\
\text { aset }\end{array}$ & & & & & $\mathrm{v}$ \\
\hline
\end{tabular}

\section{KESIMPULAN}

Berdasarkan hasil analisis dan pembahasan dapat ditarik kesimpulan bahwa implementasi Sistem Informasi di PT.Serasi Autoraya (Trac) masih terbatas, karena selama ini hanya mengandalkan System Application and Product (SAP). Oleh karena itu, direkomendasikan untuk pengembangan beberapa sistem informasi untuk mendukung bisnis perusahaan, yaitu: Website trac, Pengembangan Aplikasi Sistem Infromasi Layanan Pelanggan, Aplikasi Sistem Informasi Aset dan Pengembangan Sistem Informasi Eksekutif. Aplikasi yang direkomendasi ini diterapkan dalam jangka waktu 5 (lima) tahun, yaitu: 2019-2023. Dengan demikian, dengan adanya rencana strategis ini diharapkan dapat memberikan kejelasan arah pengembangan sistem informasi kedepan sesuai dengan kebutuhan organisasi.

\section{SARAN}

Saran kedepannya untuk peneliti selanjutnya dapat memberikan dan menerapkan perencanaan strategis SI yang tepat harus melalui tahapan perencanaan strategis sistem informasi. Penelitian ini fokus pada aplikasi sistem informasi maka kedepan perlu mengkaji aspek teknologi informasi yaitu hardware, jaringan dan integrasi sistem. Selain itu, rencana pengembangan kapasitas SDM SI/TI sesuai dengan kebutuhan organisasi, misalnya dalam bidang teknisi hardware, programming dan analisis sistem.

\section{DAFTAR PUSTAKA}

Anharudin. 2015. "Perencanaan Strategis Sistem Informasi Untuk Meningkatkan Pelayanan Menggunakan Metode Ward And Peppard ( Studi Kasus : Pt Pos Indonesia Cilegon - Banten)," Jurnal PROSISKO, 2(2), hal. 1-4. Tersedia pada: http://e- 
jurnal.lppmunsera.org/index.php/PROSISKO/article /view/103/161.

Arifani dan Darmawan. 2016. "Perencanaan Strategis Sistem Informasi Dan Teknologi Informasi SI / TI Pendidik Dan Tenaga Kependidikan ( Studi Kasus : Pada Disdikbudpora Metro )," TIM Darmajaya, 02(01), hal. 41-51. Tersedia pada: https://jurnal.darmajaya.ac.id/index.php/jtim/article/ view/646/430.

Kadir, A. (2014) Pengenalan Sistem Informasi Edisi Revisi. Yogyakarta: Andi Offset.

Kurniadi dan Mulyani. 2016. "Implementasi Pengembangan Student Information Terminal (S-IT) Untuk Pelayanan Akademik Mahasiswa," Jurnal Algoritma, 13(1), hal. 437-442. Tersedia pada: https://www.researchgate.net/publication/314551718 _Implementasi_Pengembangan_Student_Informatio n_Terminal_SIT_Untuk_Pelayanan_Akademik_Mahasiswa.

Santoso, Rasidi dan Arif. 2018. "Perencanaan Arsitektur Enterpise Sistem Informasi Untuk Perguruan Tinggi Dengan Zachman Framework," RESEARCH : Computer, Information System \& Technology Management, 1(02), hal. 32. doi: 10.25273/research.v1i02.3350.

Septiana, Y. 2017. "Perencanaan Strategis Sistem Informasi Dengan Pendekatan Ward and Peppard Model (Studi Kasus: Klinik INTI Garut)," Jurnal Wawasan Ilmiah, 8(1), hal. 8-24. Tersedia pada: https://jurnal.amikgarut.ac.id/index.php/jwi/article/vi ew/28.

Setiawan, H. S. 2016. "Perencanaan Strategis Sistem Informasi PT.FM Guna Meningkatkan Daya Saing Menggunakan Metode Ward \&amp; Peppard," STRING (Satuan Tulisan Riset dan Inovasi Teknologi), 1(2), hal. 130. doi: 10.30998/string.v1i2.1032.

Syafitri, W. 2015. "Perencanaan Strategi Sistem Informasi / Teknologi Informasi Universitas Lancang Kuning," Jurnal Teknologi Informasi \& Komunikasi Digital Zone, 7(1), hal. 31-43. doi: https://doi.org/10.31849/digitalzone.v7i1.523.

Ward dan Peppard. 2002. Strategic Planning for Information Systems. London: John. Wiley \& Sons Ltd.

Wibowo dan Wijaya. 2018. "Perencanaan Strategis Si / Ti Menggunakan Metode Ward and Peppard ( Studi Kasus : Sinode GKJ )," in. Surabaya: SESINDO 2018, hal. 39-44. Tersedia pada: http://is.its.ac.id/pubs/oajis/index.php/home/detail/1 822/Perencanaan-Strategis-Siti-MenggunakanMetode-Ward-And-Peppard-Studi-Kasus-SinodeGkj. 